\title{
Notoginsenoside R1 significantly promotes in vitro osteoblastogenesis
}

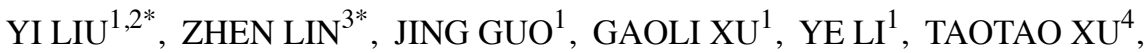 \\ HUIQING $\mathrm{LV}^{5}$, JIANZHI CHEN ${ }^{1}$ and GANG WU ${ }^{2}$ \\ ${ }^{1}$ School of Stomatology, Zhejiang Chinese Medical University, Hangzhou, Zhejiang 310053, P.R. China; \\ ${ }^{2}$ Department of Oral Implantology and Prosthetic Dentistry, Academic Centre for Dentistry Amsterdam (ACTA), \\ VU University Amsterdam and University of Amsterdam, MOVE Research Institute, 1081 LA Amsterdam, \\ Nord-Holland, The Netherlands; ${ }^{3}$ Department of Orthopedics, The First Affiliated Hospital of Jinan University, \\ Guangzhou, Guangdong 510630; ${ }^{4}$ The First Clinical Medical College and ${ }^{5}$ School of Pharmacy, \\ Zhejiang Chinese Medical University, Binjiang, Hangzhou, Zhejiang 310053, P.R. China
}

Received October 24, 2015; Accepted June 9, 2016

DOI: 10.3892/ijmm.2016.2652

\begin{abstract}
Notoginsenoside R1 (NGR1), one of the main effective components of Panax notoginseng, appears to be effective in promoting osteogenesis and treating osteoporosis. However, hitherto, whether NGR1 can directly promote osteoblastogenesis remains to be elucidated. In the present study, we hereby examined the effects of NGR1 on the osteoblastogenesis of a pre-osteoblast cell line (MC3T3-E1) in in vitro time-course and dose-dependent experiments. Its efficacy was evaluated by assessing cell viability (indicator of proliferation), alkaline phosphatase (ALP) activity (a marker of early osteoblastic differentiation), levels of osteocalcin (OCN; a marker of late osteoblastic differentiation), calcium deposition (a marker of final mineralization) and the expression of a series of osteoblastogenic marker genes (such as collagen I $\alpha$, Runx2, ALP and OCN) at different time points. When examining the proliferation of and ALP activity in the pre-osteoblasts, a bell-shaped dose-response pattern was observed when the
\end{abstract}

Correspondence to: Dr Jianzhi Chen, School of Stomatology, Zhejiang Chinese Medical University, Binwen Road 548, Binjiang, Hangzhou, Zhejiang 310053, P.R. China

E-mail: chenj_z@163.com

Dr Gang Wu, Department of Oral Implantology and Prosthetic Dentistry, Academic Centre for Dentistry Amsterdam (ACTA), VU University Amsterdam and University of Amsterdam, MOVE Research Institute, Gustav Mahlerlaan 3004, 1081 LA Amsterdam, Nord-Holland, The Netherlands

E-mail: g.wu@acta.nl

*Contributed equally

Key words: notoginsenoside R1, osteocalcin, alkaline phosphatase, mineralization, osteogenesis cells were treated with various concentrations of NGR1, with a peak being observed at the concentration of $50 \mu \mathrm{g} / \mathrm{ml}$. NGR1 markedly increased the expression of OCN at the concentration of $1,000 \mu \mathrm{g} / \mathrm{ml}$ in a dose-dependent manner. Furthermore, treatment with $1,000 \mu \mathrm{g} / \mathrm{ml}$ NGR1 resulted in the highest mineralization by 4.3 - and 5.9-fold on the 21st and 28th day, respectively compared with the control group (no treatment). On the whole, our findings indicate that NGR1 significantly promotes the osteoblastogenesis of pre-osteoblasts, which suggests that NGR1 has potential for use as a bone regeneration agent.

\section{Introduction}

Sufficient bone volume and adequate bone quality are of paramount importance to achieve the rapid establishment of implant functions in dentistry and orthopedics. However, various adverse bone conditions, such as bone defects, low bone density and compromised self-healing capacity can significantly compromise new bone regeneration and implant osteointegration, thus delaying the loading of implants (1). Autologous bone grafts are still regarded as the 'gold standard' to repair bone defects since they contain osteoinductive growth factors and osteogenic cells (2). However, theirs use is limited due to intrinsic disadvantages, such as limited availability and donor-site pain. In addition, the efficacy of autologous bone grafts can also be compromised when the patients have low bone density or a compromised healing capacity. As alternatives to autologous bone grafts, various bioactive agents that are used either alone or in combination with biomaterials have been resorted to promote bone regeneration (3). Bone morphogenetic proteins (BMPs), a group of proteinaceous growth factors, are the most extensively used agents for bone regeneration (4). However, the effective doses of homodimeric BMPs used clinically to induce bone formation are very high (e.g., up to several milligrams) $(5,6)$, which leads to not only a substantial economic burden, but also to a series of potential side-effects, such as the overstimulation of osteoclastic activity 
in the surrounding milieu and ectopic bone formation in unintended areas $(7,8)$. Gene, cell and cytokine therapies have been reported to substitute autografting, but due to the high cost associated with their use, they have not been widely used clinically (9-11). In comparison, traditional Chinese medicine has attracted increasing attention, as it involves the use of agents that possess high bioactivity and have minimal side-effects.

One of such traditional Chinese medicine is Panax notoginseng saponins (PNS), a mixture of active compounds that are extracted from the Panax notoginseng root. Panax notoginseng has been widely used as a medicinal herb for over thousands of years in China and exhibits minimal side-effects, which is a great advantage. PNS has been widely used in the treatment of cardiovascular diseases (12). Recently, PNS was found to protect rabbit bone marrow stromal cells from oxidative stress-induced damage and apoptosis by scavenging ROS and regulating the Bcl-2/Bax pathway, thereby promoting bone formation (13). Another study also confirmed that PNS promoted the osteogenesis of bone marrow stromal cells by activating the ERK and p38 signaling pathways (14). PNS also promotes the proliferation and osteogenic differentiation of NIH3T3 fibroblasts by increasing the phosphorylation of ERK1/2 protein kinase (15). PNS can also promote the development of osteoblasts $(16,17)$. These findings suggest that some effective components in PNS have the potential to be used clinically to promote osteogenesis. Notoginsenoside R1 (NGR1) is one of the main constituents of PNS. Unlike other pharmacologically active saponins in both PNS and other species of ginseng, NGR1 is found only in PNS $(18,19)$. However, hitherto, whether NGR1 can directly affect osteoblastogenesis remains to be elucidated.

In this study, we aimed to examine the effects of NGR1 on the osteoblastogenesis of a pre-osteoblast cell line (MC3T3E1 cells) in time-course and dose-dependent experiments. We evaluated its effects by assessing cell viability (an indicator of proliferation), alkaline phosphatase (ALP) activity (a marker of early osteogenic differentiation), levels of osteocalcin (OCN; a marker of late osteogenic differentiation), calcium deposition (a marker of final mineralization) and the expression of osteoblastogenic marker genes (such as Runx2, collagen I $\alpha$, ALP and $\mathrm{OCN}$ ) at different time points.

\section{Materials and methods}

Cell culture. MC3T3-E1 (subclone 14; ATCC CRL-2594) pre-osteoblasts were obtained from ATCC, Manassas, VA, USA. The cells were cultured in a $\alpha$-minimum essential medium ( $\alpha$-MEM) containing 10\% fetal bovine serum (FBS) (Gibco ${ }^{\circledR}$, Invitrogen, Grand Island, NY, USA). The medium was changed every 3 days. Triplicate experiments per group were performed for each parameter per time point. The exponentially growing cells were collected and seeded at a final concentration of $1 \times 10^{4}$ cells/well in 24-well plates for the cell proliferation assay. For the ALP activity assay, OCN detection and polymerase chain reaction (PCR), the cells were seeded in 6 -well plates at a final concentration of $2 \times 10^{5}$ cells/well or in 48 -well plates at a final concentration of $3 \times 10^{4}$ cells/well for Alizarin red staining. Twenty-four hours post-incubation, the cells were subjected to a low-serum medium $(\alpha-\mathrm{MEM}$ containing 2\% FBS) for another $24 \mathrm{~h}$. Thereafter, the cells were treated with various concentrations $(0,5,50,100,20$ and
1,000 $\mu \mathrm{g} / \mathrm{ml}$ ) of NGR1 (ZL140310529; Nanjing Zelang Medical Technological Co., Ltd., Nanjing, China.

Cell viability and proliferation assay. The viability and proliferation of the MC3T3-E1 cells in each treatment group (various concentrations of NGR1) were determined using the Alamar Blue cell viability reagent (Invitrogen, Carlsbad, CA, USA) following treatment with NGR1 for 1, 4 and 7 days. We used a fluorescence spectrometer (SpectraMax M5; Molecular Devices, Sunnyvale, CA, USA) to measure the fluorescence intensity with the excitation wavelength at $540 \mathrm{~nm}$ and the emission wavelength at $590 \mathrm{~nm}$.

ALP activity assay. The ALP activity and total protein content were measured following treatment for 4 and 7 days to assess the early differentiation of the pre-osteoblasts. The ALP activity in the whole cell lysate was determined using a LabAssay ${ }^{\mathrm{TM}}$ ALP colorimetric assay kit (Wako Pure Chemicals, Osaka, Japan). The ALP activity was normalized by the total protein content that was measured using a commercial BCA protein assay kit (Beyotime, Haimen, China).

OCN expression assay. OCN expression in the cell culture medium after the 4- and 7-day treatments was determined to assess the terminal differentiation of the pre-osteoblasts. The OCN concentrations were determined using a mouse OCN EIA kit (Biomedical Technologies, Stoughton, MA, USA), as previously described (20).

Alizarin red staining. In order to assess the extracellular mineralization of the MC3T3-E1 cells, osteogenic medium (10\% FBS, $50 \mu \mathrm{g} / \mathrm{ml} \mathrm{L}$-ascorbic acid and $10 \mathrm{mM}$ $\beta$-glycerophosphate; Sigma-Aldrich, St. Louis, MO, USA) containing various concentrations of NGR1 was used to treat the cells for 21 and 28 days (21). On the 21st and 28th day, mineralized nodules were stained with Alizarin red (Sigma-Aldrich) as previously described (22). The calcified areas were photographed and then quantified using Image-Pro Plus 6.0 software.

Isolation of total RNA and reverse transcription-quantitative $P C R(R T-q P C R)$. On the 4th and the 7th day, total RNA was extracted using a RNeasy mini kit and purified with RNaseFree DNase set reagent (Qiagen, Hilden, Germany) according to the manufacturer's instructions. Total RNA was reverse transcribed into cDNA using PrimeScript ${ }^{\circledR}$ RT Master Mix (Perfect Real-Time; Takara, Otsu, Japan). A PrimeScript ${ }^{\circledR}$ RT reagent kit (Perfect Real-Time; Takara) was used to perform RT-qPCR. The primers for detecting mRNA transcripts of the collagen I $\alpha$, Runx 2 , ALP, OCN and $\beta$-actin genes were designed as previously published and are shown in Table $I(1,4)$. The transcripts were normalized to the $\beta$-actin transcript levels. The n-fold upregulation for each gene over the internal control gene ( $\beta$-actin gene) was calculated according to the $\Delta \Delta \mathrm{Ct}$ method using the formula following: $2^{-[(\mathrm{CT} \text { gene of interest }-\mathrm{CT} \text { internal }}$ control)sample - (CT gene of interest - CT internal control)control], as previously described (23).

Statistical analysis. Statistical comparisons among the results were made by one-way analysis of variance (ANOVA) with Bonferroni corrections for post hoc comparisons. The level of 
Table I. Primers used for RT-qPCR.

\begin{tabular}{|c|c|c|}
\hline Gene & Accession no & Primer sequences \\
\hline Akp2 & NM_007431 & F: 5'-TGCCTACTTGTGTGGCGTGAA-3' \\
\hline$(\mathrm{ALP})$ & & R:5'-TCACCCGAGTGGTAGTCACAATG-3 \\
\hline Osteocalcin & NM_007541 & F: 5'-AGCAGCTTGGCCCAGACCTA-3' \\
\hline$(\mathrm{OCN})$ & & R:5'-TAGCGCCGGAGTCTGTTCACTAC-3 \\
\hline \multirow[t]{2}{*}{ Collagen I } & NM_007742 & F: 5'-ATGCCGCGACCTCAAGATG-3' \\
\hline & & R:5'-TGAGGCACAGACGGCTGAGTA-3' \\
\hline \multirow[t]{2}{*}{ Runx2 } & NM_009820 & F: 5'-CACTGGCGGTGCAACAAGA-3' \\
\hline & & R:5'-TTTCATAACAGCGGAGGCATTTC-3 \\
\hline \multirow[t]{2}{*}{$\beta$-actin } & NM_007393 & F: 5'-AGGAGCAATGATCTTGATCTT-3' \\
\hline & & R:5'-TGCCAACACAGTGCTGTCT-3' \\
\hline
\end{tabular}

F, forward; R, reverse; ALP, alkaline phosphatase; OCN, osteocalcin.

significance was set at $\mathrm{p}<0.05$. SPSS software (version 20) was adopted for the statistical analysis.

\section{Results}

Cell proliferation. The effect of NGR1 on cell proliferation exhibited a bell-shaped dose-dependent pattern. On the 1st day of treatment, a significant increase in the cell numbers was detected when the cells were treated with $50 \mu \mathrm{g} / \mathrm{ml}$ NGR1 (Fig. 1). In comparison with the control (no treatment), treatment with NGR1 at 5, 50 and $100 \mu \mathrm{g} / \mathrm{ml} \mathrm{NGR} 1$ resulted in significantly increased cell viability (1.6,2.2 and 1.9-fold of the control, respectively), while treatment with NGR1 at 200 and $1,000 \mu \mathrm{g} / \mathrm{ml}$ resulted in significant lower cell numbers. The cell numbers increased significantly with as time progressed with all NGR1 concentrations. On the 4th and 7th day of treatment, treatment with 50 and $100 \mu \mathrm{g} / \mathrm{ml}$ NGR1 led to significantly higher cell numbers, while treatment with 200 and $1,000 \mu \mathrm{g} / \mathrm{ml}$ NGR1 resulted in significantly lower cell numbers compared to the controls. The most prominent promoting effects of NGR1 on cell proliferation were observed at the concentration of $50 \mu \mathrm{g} / \mathrm{ml}$, and the greatest inhibitory effects on proliferation were observed at the concentration of $1,000 \mu \mathrm{g} / \mathrm{ml}$.

ALP activity. Similar to its effects on cell proliferation, the effect of NGR1 on ALP activity also exhibited a bell-shaped dose-dependent pattern. On the 4th day of treatment, NGR1 at the concentrations of 5 to $200 \mu \mathrm{g} / \mathrm{ml}$ significantly enhanced ALP activity, with a peak being observed at the concentration of $50 \mu \mathrm{g} / \mathrm{ml}$. Treatment with NGR1 at $1,000 \mu \mathrm{g} / \mathrm{ml}$ did exert a significant modulatory effect in comparison with the control. On the 7th day, treatment with only $50 \mu \mathrm{g} / \mathrm{ml}$ NGR 1 resulted in significantly higher ALP activity in comparison with the control group (no NGR1). By contrast, treatment with NGR1 at 100,200 or $1,000 \mu \mathrm{g} / \mathrm{ml}$ led to a significantly lower ALP activity, with the lowest value being observed at the concentration of $1,000 \mu \mathrm{g} / \mathrm{ml}$.

OCN expression. After the 4-day treatment, NGR1-induced OCN expression exhibited a dose-dependent increasing trend. With NGR1, OCN expression in the pre-osteoblasts significantly increased from the 4th to the 7 th day of treatment for each concentration (Fig. 3). Different from its effects on cell proliferation and ALP activity, the effect of NGR1 on OCN expression exhibited a dose-dependent increasing pattern. On the 7 th day in particular, treatment with $1,000 \mu \mathrm{g} / \mathrm{ml}$ NGR1 significantly increased OCN expression by almost 5 -fold in comparison with the control (no NGR1) (Fig. 3).

Cell matrix mineralization. In the control group, rare mineralization was observed (Fig. 4). On the 21st and 28th day of treatment, mineralization in the cell matrix was observed in

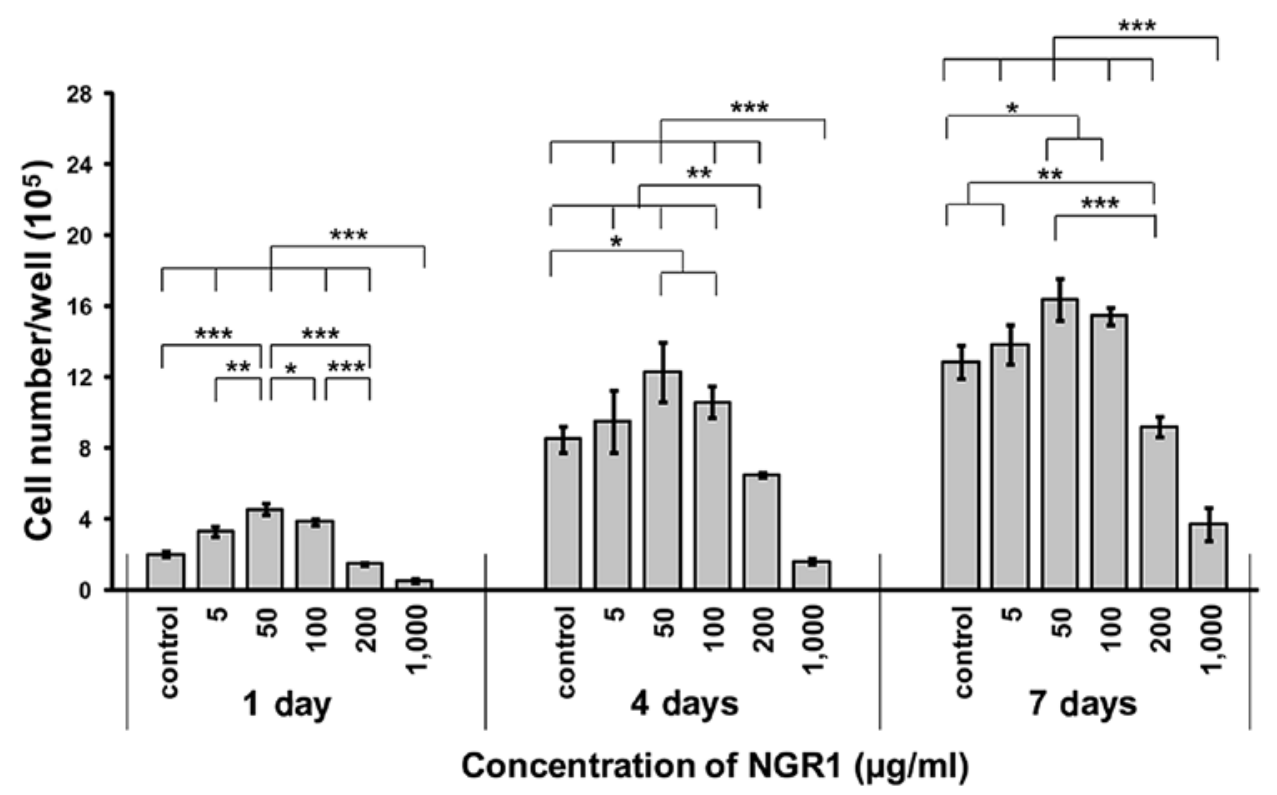

Figure 1. Numbers of murine calvarial pre-osteoblasts (MC3T3-E1 cell line) per well under the different treatment conditions: i) control (no treatment); ii) $5 \mu \mathrm{g} /$ $\mathrm{ml}$ notoginsenoside R1 (NGR1); iii) $50 \mu \mathrm{g} / \mathrm{ml} \mathrm{NGR1;} \mathrm{iv)} 100 \mu \mathrm{g} / \mathrm{ml} \mathrm{NGR1;} \mathrm{v)} 200 \mu \mathrm{g} / \mathrm{ml} \mathrm{NGR1;} \mathrm{vi)} 1,000 \mu \mathrm{g} / \mathrm{ml} \mathrm{NGR} 1$ for 1, 4 and 7 days. Data are presented as the mean values and the corresponding standard deviation (SD). ${ }^{*} \mathrm{p}<0.05,{ }^{* *} \mathrm{p}<0.01$ and ${ }^{* * *} \mathrm{p}<0.001$. 


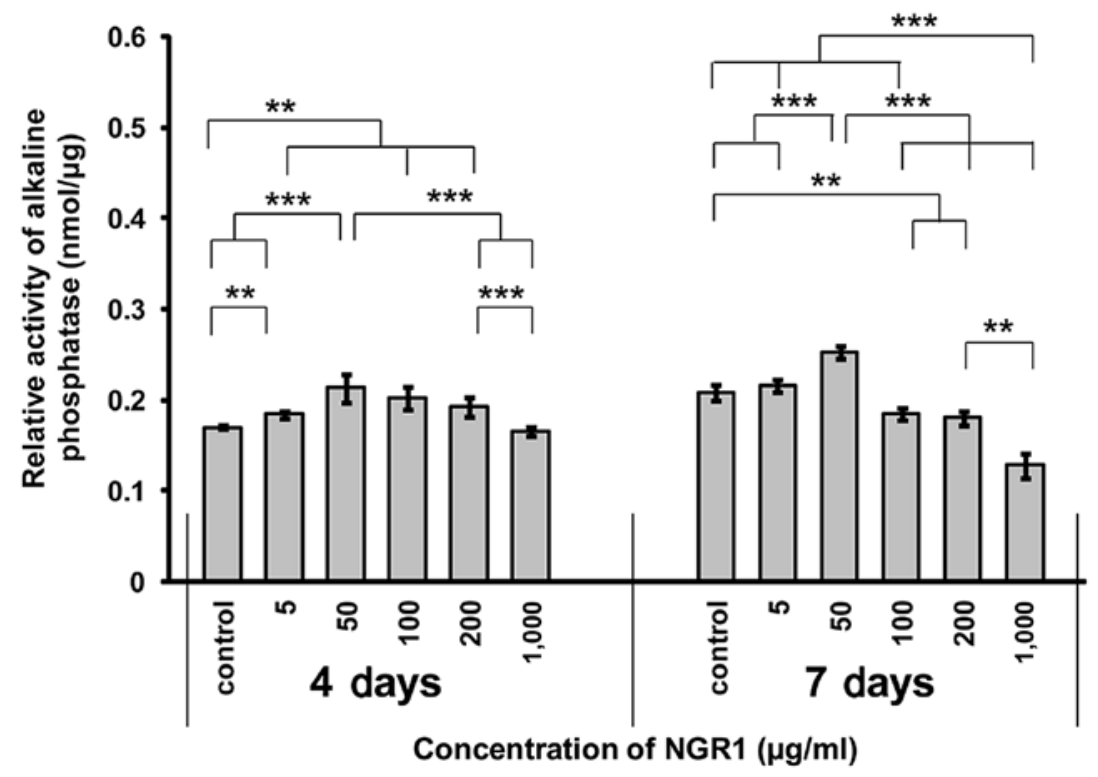

Figure 2. Activity of alkaline phosphatase (ALP) in murine calvarial pre-osteoblast (MC3T3-E1 cells) under the different treatment conditions: i) control (no treatment) ii) $5 \mu \mathrm{g} / \mathrm{ml}$ notoginsenoside R1 (NGR1); iii) $50 \mu \mathrm{g} / \mathrm{ml} \mathrm{NGR1;} \mathrm{iv)} 100 \mu \mathrm{g} / \mathrm{ml} \mathrm{NGR1;} \mathrm{v)} 200 \mu \mathrm{g} / \mathrm{ml} \mathrm{NGR1;} \mathrm{vi)} \mathrm{1,000} \mu \mathrm{g} / \mathrm{ml} \mathrm{NGR1} \mathrm{for} 4$ and 7 days. Data are presented as the mean values and the corresponding standard deviation (SD). ${ }^{*} \mathrm{p}<0.05,{ }^{* *} \mathrm{p}<0.01$ and ${ }^{* * *} \mathrm{p}<0.001$.

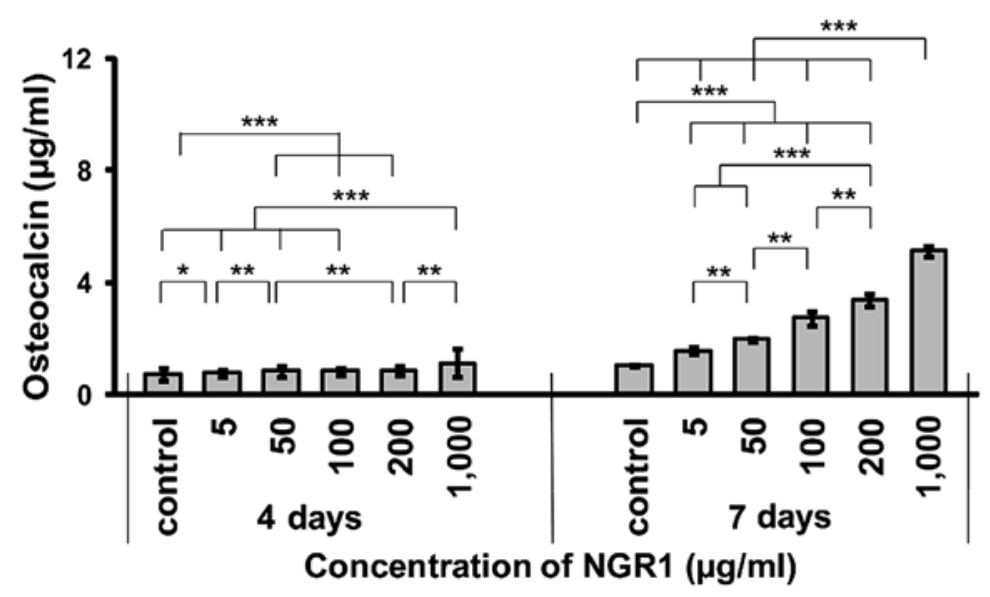

Figure 3. Expression of osteocalcin $(\mathrm{OCN})$ in murine calvarial pre-osteoblasts (MC3T3-E1 cells) under the different treatment conditions: i) control (no treatment); ii) $5 \mu \mathrm{g} / \mathrm{ml}$ notoginsenoside R1 (NGR1); iii) $50 \mu \mathrm{g} / \mathrm{ml} \mathrm{NGR1;} \mathrm{iv)} 100 \mu \mathrm{g} / \mathrm{ml} \mathrm{NGR} 1$; v) $200 \mu \mathrm{g} / \mathrm{ml}$ NGR1; vi) $1,000 \mu \mathrm{g} / \mathrm{ml}$ NGR1 for 4 and $7 \mathrm{days}$. Data are presented as the mean values and the corresponding standard deviation (SD). ${ }^{*} \mathrm{p}<0.05,{ }^{* *} \mathrm{p}<0.01$ and ${ }^{* * * *} \mathrm{p}<0.001$.

the cells treated with NGR1. Treatment with NGR1 at 100,200 and $1,000 \mu \mathrm{g} / \mathrm{ml}$ significantly enhanced mineralization in comparison with the control group on the 21st day. Treatment with NGR1 at $1,000 \mu \mathrm{g} / \mathrm{ml}$ resulted in the highest mineralization (4.3 and 5.9-fold on the 21st and 28th day, respectively) compared with the control group.

Expression of osteogenic genes. Runx 2 gene is key to control the proliferation of osteoblasts and to promote the stage of cell proliferation to osteogenic differentiation $(24,25)$. In this study, we found that on the 4th day of treatment, NGR1 at all the selected concentrations significantly enhanced the mRNA expression of Runx2, exhibiting a bell-shaped dose-dependent pattern. The highest expression of Runx 2 mRNA was resulted from $50 \mu \mathrm{g} / \mathrm{ml} \mathrm{NGR1} \mathrm{(Fig.} \mathrm{5A).} \mathrm{On} \mathrm{the} \mathrm{7th} \mathrm{day,} \mathrm{in} \mathrm{comparison}$ with the control (no NGR1), treatment with 50, 100 and $200 \mu \mathrm{g}$ / ml NGR1 resulted in a significantly higher mRNA expression of Runx2, whereas treatment with $1,000 \mu \mathrm{g} / \mathrm{ml}$ NGR1 resulted in a significantly lower expression.

On the 4th day of treatment, the expression of the collagen I $\alpha$ gene was significantly enhanced by $50 \mu \mathrm{g} / \mathrm{ml}$ NGR1, while it was significantly suppressed by $1,000 \mu \mathrm{g} / \mathrm{ml}$ NGR1 (Fig. 5B). On the 7th day, NGR1 at 50 to $1,000 \mu \mathrm{g} / \mathrm{ml}$ significantly enhanced the mRNA expression of collagen I $\alpha$. Treatment with NGR1 at $50 \mu \mathrm{g} / \mathrm{ml}$ induced the greatest increase in collagen $\mathrm{I} \alpha$ at both time points.

Consistent with ALP activity, the highest mRNA expression of ALP was observed in the cells treated with $50 \mu \mathrm{g} / \mathrm{ml}$ NGR1 on both the 4th and 7th day (Fig. 5C). On the 7th day, treatment with 200 and 1,000 $\mu \mathrm{g} / \mathrm{ml}$ NGR1 significantly downregulated the mRNA expression of ALP in comparison with the control group. Consistent with its effect on OCN expression, NGR1 exhibited a dose-dependent increasing pattern in promoting the mRNA expression of OCN (Fig. 5D). The mRNA expres- 

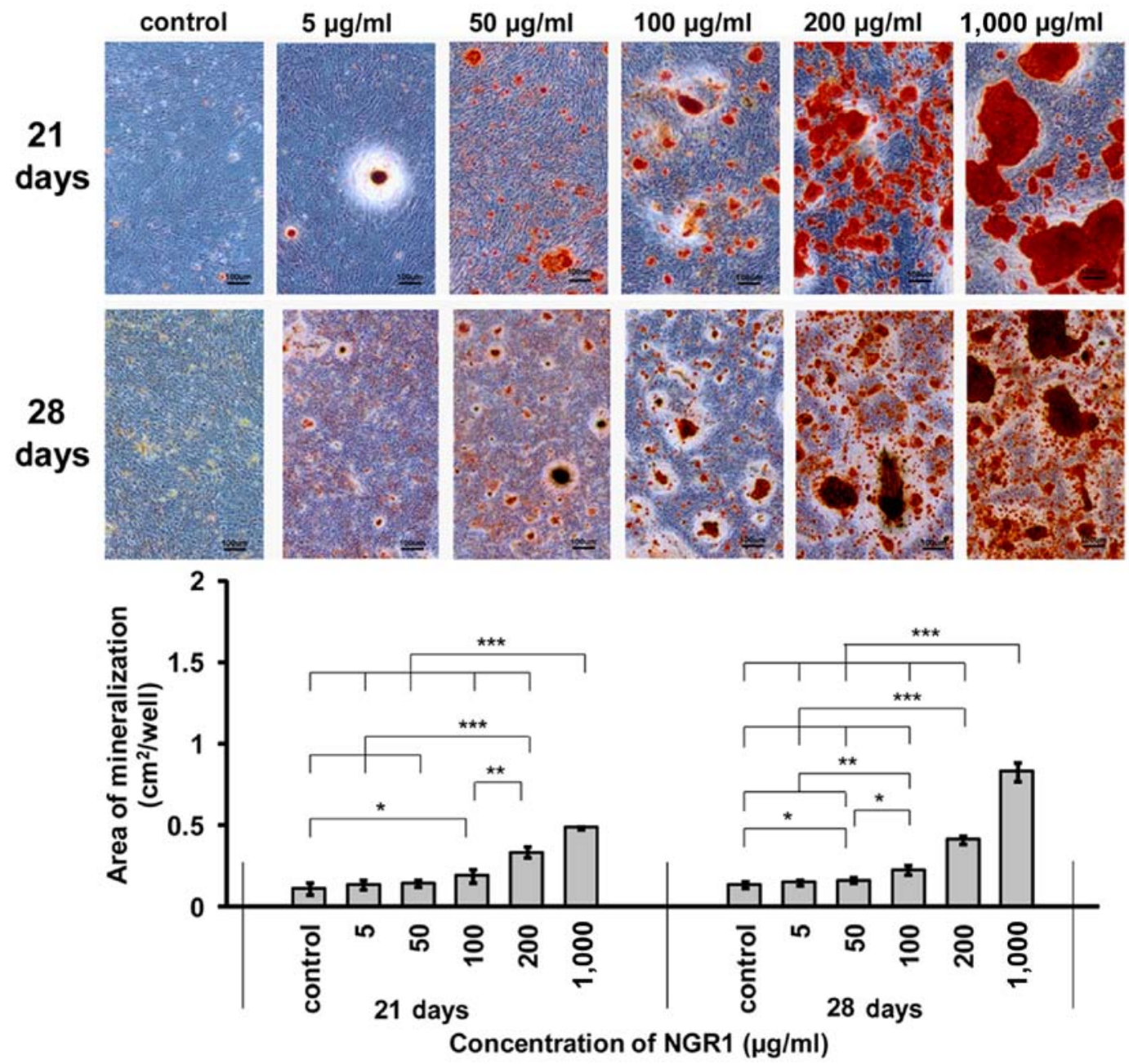

Figure 4. Mineralization of murine calvarial pre-osteoblasts (MC3T3-E1 cells) under the different treatment conditions: i) control (no treatment); ii) $5 \mu \mathrm{g} / \mathrm{ml}$ notoginsenoside R1 (NGR1); iii) $50 \mu \mathrm{g} / \mathrm{ml} \mathrm{NGR1;} \mathrm{iv)} 100 \mu \mathrm{g} / \mathrm{ml} \mathrm{NGR1;} \mathrm{v)} 200 \mu \mathrm{g} / \mathrm{ml} \mathrm{NGR1;} \mathrm{vi)} 1,000 \mu \mathrm{g} / \mathrm{ml}$ NGR1. (4-1) Light micrographs depicting Alizarin red staining on the 21st day and 28th day. (4-2) Graph depicting the calcification area on the 21st and 28th day. Data are presented as the mean values and the corresponding standard deviation (SD). ${ }^{*} \mathrm{p}<0.05,{ }^{* *} \mathrm{p}<0.01$ and ${ }^{* * *} \mathrm{p}<0.001$.

sion of OCN increased significantly as time progressed with all selected concentrations. NGR1 at $1,000 \mu \mathrm{g} / \mathrm{ml}$ resulted in the highest mRNA expression of OCN (1.8 and 1.7-fold on the 4 th and 7 th day, respectively) compared with the control.

\section{Discussion}

Bone regeneration is a delicately orchestrated activity of osteoblasts with coupling bone remodeling by osteoclasts. A number of Chinese medicinal herbs have been used to promote bone formation in fractures in China for over a thousand years. In modern traditional Chinese medicine, effective compositions are extracted from these herbs to treat bone diseases. For example, Ligustri Lucidi Fructus, Drynaria fortunei, Du-Zhong cortex and Icariin, can effectively correct pathological bone metabolism by promoting osteoblastogenesis and osteoblastic activity (26-28). Other extracts, such as Cinnamomum zeylanicum, can significantly inhibit RANKLinduced osteoclastogenesis and osteoclastic resorption (29). In a previous study using an in vivo rat model of osteoporosis, Cervi Cornu Pantotrichum, the main effective component of antlers, inhibited the progression of osteoporosis and promoted bone formation (30). All these findings indicate their promising potential for clinical application.

PNS, a traditional Chinese herbal medicine, has exhibited a wide range of pharmacological effects, such as angiogenetic, anti-neoplastic, neuroprotective, anti-inflammatory and immunomodulatory effects (31-35). These well-known effects confer that PNS has a strong ability to suppress pathological bone loss. PNS in combination with granulocyte colony-stimulating factor-mobilized peripheral blood mononuclear cells has been shown to cure unreconstructable critical limb ischemia (36). As an immune modulator, PNS has been shown to significantly decrease lipopolysaccharide-induced alveolar bone loss and the expression of matrix metalloproteinase- 9 in a model of periodontitis (37). Recently, PNS has been shown to directly enhance the proliferation and osteogenic differentiation of bone marrow stromal cells by modulating intercellular communication activities and activating the ERK and p38 MAPK signaling pathways $(13,14,16)$. Canonical Wnt signaling is required for the PNS-induced suppression of the nuclear factor- $\kappa \mathrm{B}$ ligand (RANKL)/osteoprotegerin (OPG) ratio in bone marrow stromal cells during osteogenic differentiation (38). NGR1, a unique and abundant component of PNS (39), has already 

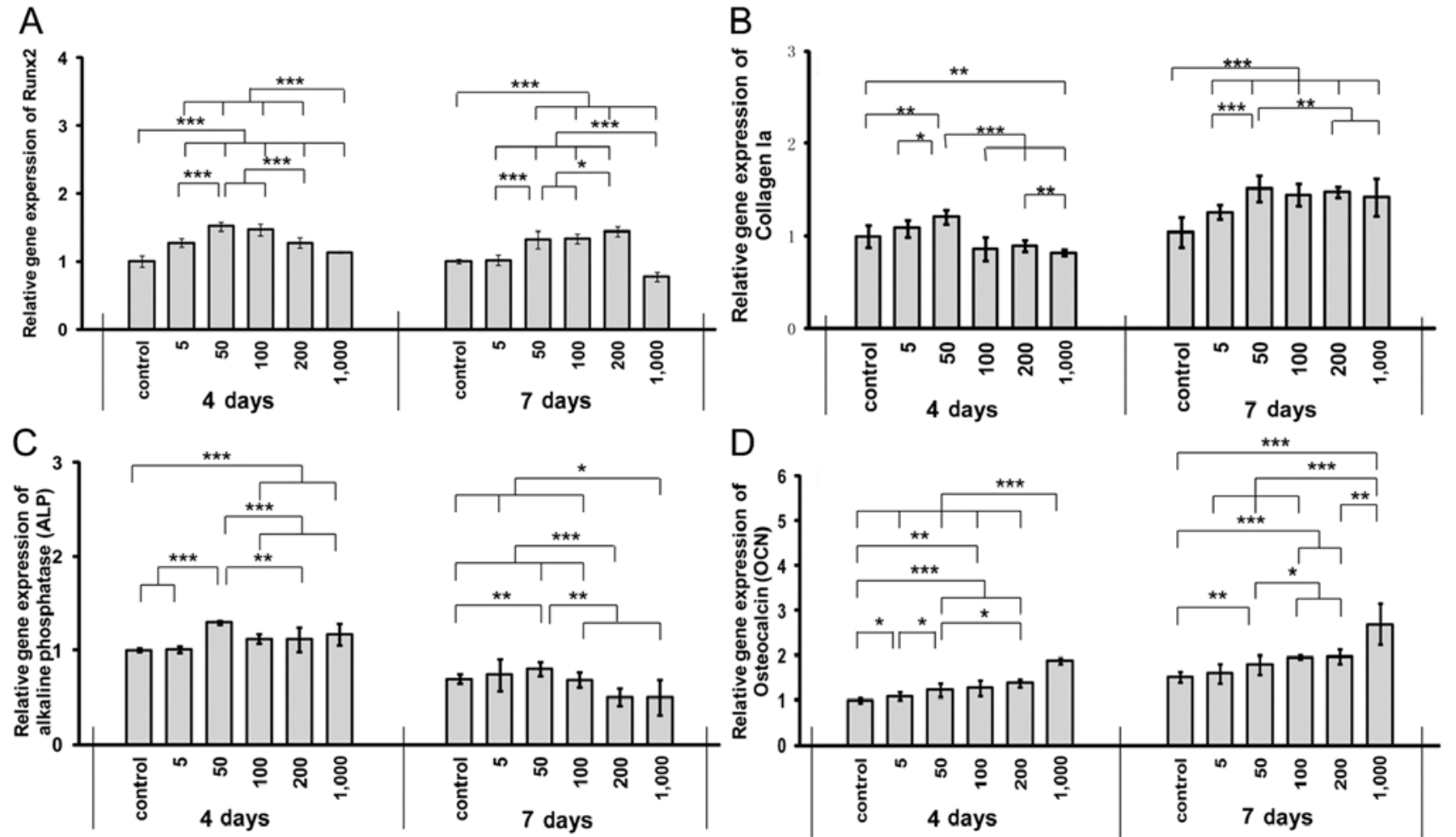

Figure 5. Relative expression of 4 osteogenic marker genes under the different treatment conditionss: i) control (no treatment); ii) $5 \mu \mathrm{g} / \mathrm{ml}$ notoginsenoside R1 (NGR1); iii) $50 \mu \mathrm{g} / \mathrm{ml} \mathrm{NGR1;} \mathrm{iv)} 100 \mu \mathrm{g} / \mathrm{ml} \mathrm{NGR1;} \mathrm{v)} 200 \mu \mathrm{g} / \mathrm{ml} \mathrm{NGR1;} \mathrm{vi)} \mathrm{1,000} \mu \mathrm{g} / \mathrm{ml}$ NGR1 for 4 and 7 days. (A) Runx2; (B) collagen I; (C) alkaline phosphatase; (D) osteocalcin. The gene expression was first normalized to the corresponding $\beta$-actin gene expression for each sample. All the gene data in each group were then normalized to the gene data in control group on the 4th day. Data are presented as the mean values and the corresponding standard deviation (SD). ${ }^{*} \mathrm{p}<0.05,{ }^{* *} \mathrm{p}<0.01$ and ${ }^{* * *} \mathrm{p}<0.001$.

been used to inhibit hypoxia-hypercapnia-induced vasoconstriction and protect cells against intestinal ischemia and reperfusion $(40,41)$. Its clinical application includes treatment of vascular disorders and osteoporosis (42). However, whether NGR1 can directly modulate osteoblastogenesis is unclear. In this study, to the best of our knowledge, through dose-dependent and time course experiments, we demonstrated for the first time that NGR1 significantly promoted in vitro osteoblastogenesis, thus suggesting that NGR1 has potential for clinical use as a bone regeneration agent.

The osteoblast phenotype is acquired in two stages. In the first stage, the matrix matures, and specific proteins associated with the bone cell phenotype (e.g., ALP) are detected. In the second stage, the matrix becomes mineralized by calcium deposition. Consequently, layers of spongy bone are formed around the original cartilage (43). In this study, the effect of NGR1 on cell proliferation and ALP activity exhibited a dose-dependent, bell-shaped pattern (Figs. 1 and 2). The optimal effects were observed at the concentration of $50 \mu \mathrm{g} / \mathrm{ml}$. NGR1 at 50 and $100 \mu \mathrm{g} / \mathrm{ml}$ significantly promoted cell proliferation (Fig. 1), while NGR 1 at 200 and $1,000 \mu \mathrm{g} / \mathrm{ml}$ significantly inhibited cell proliferation in comparison to the control (no NGR1) (Fig. 1). Consistently, the expression of collagen I $\alpha$ reached peak levels following treatment with $50 \mu \mathrm{g} / \mathrm{ml}$ NGR1 (Fig. 5B); collagen I $\alpha$ is a primary gene product of osteoblasts during bone matrix formation and comprises $85-90 \%$ of the total organic bone matrix (44). On the 4th day, treatment with 5 to $200 \mu \mathrm{g} / \mathrm{ml} \mathrm{NGR} 1$ exerted a significant promoting effect on ALP activity with peak levels being observed at the concentration of $50 \mu \mathrm{g} / \mathrm{ml}$. On the 7th day, 100 to $1,000 \mu \mathrm{g} / \mathrm{ml}$ NGR1 of showed a significant inhibiting effect on ALP activities (Fig. 2). Analogous with ALP activity, peak levels in ALP gene expression were also observed at the concentration of $50 \mu \mathrm{g} / \mathrm{ml} \mathrm{NGR1} \mathrm{(Fig.} \mathrm{5C).}$ On the 7th day, treatment with 200 and 1,000 $\mu \mathrm{g} / \mathrm{ml} \mathrm{NGR1}$ inhibited ALP gene expression. Of note, the effect of NGR1 on OCN expression exhibited a dose-dependent increasing pattern (Fig. 3). A time-dependent and dose-dependent pattern was also observed in OCN gene expression (Fig. 5D).

After culturing these pre-osteoblasts in mineralization medium for 21 days, we observed that $1,000 \mu \mathrm{g} / \mathrm{ml} \mathrm{NGR1}$ produced more bone nodules than the other concentrations (Fig. 4). A time-dependent and dose-dependent pattern was also observed in mineralization (Fig. 4). Treatment with NGR1 at $1,000 \mu \mathrm{g} / \mathrm{ml}$ significantly enhanced mineralization 5.9-fold (Fig. 4), whereas ALP activity was inhibited at this concentration (Fig. 2). By contrast, the pattern of NGR1 in promoting mineralization (Fig. 4) was consistent with that in promoting OCN expression (Fig. 3). This result suggested that the promoting effect of NGR1 on mineralization may be partially attributed to its promoting effect on OCN, but not on ALP activity. These results suggested that high levels of NGR1 can significantly enhance osteoblastogenesis, thereby suggesting that NGR1 may hold promise and great potential for use as an agent to facilitate bone regeneration and implant osteointegration in patients.

Hitherto, the molecular mechanisms accounting for the promoting effects of NGR1 on osteoblastogenesis remain unveiled. Runx2, a key modulator of osteogenic differentia- 
tion, controls osteoblast proliferation and promotes a transition from a proliferative to a post-proliferative stage prior to osteoblast differentiation $(24,25)$. In this study, Runx 2 expression significantly increased under the stimulation of $50 \mu \mathrm{g} /$ $\mathrm{ml}$ NGR1, whereas it significantly decreased in the presence of $1,000 \mu \mathrm{g} / \mathrm{ml} \mathrm{NGR1} \mathrm{(Fig.} \mathrm{5A).} \mathrm{This} \mathrm{result} \mathrm{suggested} \mathrm{that}$ the highest mineralization in response to $1,000 \mu \mathrm{g} / \mathrm{ml}$ NGR 1 was not due to the upregulation of Runx2. A previous study demonstrated that the induction of ALP activity was mediated through the activation of a Smad-independent signaling pathway p38 MAPK (45). OCN is a late differentiation marker for osteoblastogenesis, which is modulated by osterix (46). It may be plausible that NGR1 at different concentrations can differentially modulate p38 MAPK and osteorix. Screening the gene expression pattern of pre-osteoblasts under the stimulation of NGR1 at different concentrations may help to further elucidate the signaling pathway involved.

One limitation in this study was that we only adopted one type of osteogenic cell line, which may behave differently from primary osteoblasts or bone marrow stromal cells. Studies using human primary mesenchymal cells may be more indicative for its clinical application potential. However, we demonstrate that NGR1 has potential for use as a bone regeneration agent.

\section{Acknowledgements}

This study was supported by the Zhejiang Traditional Chinese Medicine Scientific Research Foundation (grant no. 2012ZA029) and the National Natural Science Foundation of China (grant no. 81400475).

\section{References}

1. Bi W, Gu Z, Zheng Y, Zhang X, Guo J and Wu G: Heterodimeric BMP-2/7 antagonizes the inhibition of all-trans retinoic acid and promotes the osteoblastogenesis. PLoS One 8: e78198, 2013.

2. Zimmermann G and Moghaddam A: Allograft bone matrix versus synthetic bone graft substitutes. Injury 42 (Suppl 2): S16-S21, 2011.

3. Shadjou N and Hasanzadeh M: Silica-based mesoporous nanobiomaterials as promoter of bone regeneration process. J Biomed Mater Res A 103: 3703-3716, 2015.

4. Zheng Y, Wu G, Zhao J, Wang L, Sun P and Gu Z: rhBMP2/7 heterodimer: An osteoblastogenesis inducer of not higher potency but lower effective concentration compared with rhBMP2 and rhBMP7 homodimers. Tissue Eng Part A 16: 879-887, 2010.

5. Govender S, Csimma C, Genant HK, Valentin-Opran A, Amit Y, Arbel R, Aro H, Atar D, Bishay M, Börner MG, et al: Recombinant human bone morphogenetic protein-2 for treatment of open tibial fractures: a prospective, controlled, randomized study of four hundred and fifty patients. J Bone Joint Surg Am 84-A: 2123-2134, 2002.

6. Boden SD, Kang J, Sandhu H and Heller JG: Use of recombinant human bone morphogenetic protein-2 to achieve posterolateral lumbar spine fusion in humans: a prospective, randomized clinical pilot trial: 2002 Volvo Award in clinical studies. Spine 27: 2662-2673, 2002.

7. Kaneko H, Arakawa T, Mano H, Kaneda T, Ogasawara A, Nakagawa M, Toyama Y, Yabe Y, Kumegawa M and Hakeda Y: Direct stimulation of osteoclastic bone resorption by bone morphogenetic protein (BMP)-2 and expression of BMP receptors in mature osteoclasts. Bone 27: 479-486, 2000.

8. Uludag H, D'Augusta D, Palmer R, Timony G and Wozney J: Characterization of rhBMP-2 pharmacokinetics implanted with biomaterial carriers in the rat ectopic model. J Biomed Mater Res 46: 193-202, 1999.

9. Sokolsky-Papkov M, Agashi K, Olaye A, Shakesheff K and Domb AJ: Polymer carriers for drug delivery in tissue engineering. Adv Drug Deliv Rev 59: 187-206, 2007.
10. Carson JS and Bostrom MP: Synthetic bone scaffolds and fracture repair. Injury 38 (Suppl 1): S33-S37, 2007.

11. Kessler P, Thorwarth M, Bloch-Birkholz A, Nkenke E and Neukam FW: Harvesting of bone from the iliac crest - comparison of the anterior and posterior sites. Br J Oral Maxillofac Surg 43: 51-56, 2005.

12. Yang $\mathrm{X}$, Xiong $\mathrm{X}$, Wang $\mathrm{H}$, Wang J: Protective effects of Panax notoginseng saponins on cardiovascular diseases: a comprehensive overview of experimental studies. Evid Based Complement Alternat Med 2014: 204840, 2014.

13. Qiang H, Zhang C, Shi ZB, Yang HQ and Wang KZ: Protective effects and mechanism of Panax notoginseng saponins on oxidative stress-induced damage and apoptosis of rabbit bone marrow stromal cells. Chin J Integr Med 16: 525-530, 2010.

14. Li XD, Liu ZY, Chang B, Liu DX, Chen B, Guo C, Wang YG, $\mathrm{Xu}$ JK, Huang DY and Du SX: Panax notoginseng saponins promote osteogenic differentiation of bone marrow stromal cells through the ERK and P38 MAPK signaling pathways. Cell Physiol Biochem 28: 367-376, 2011.

15. Yin LM, Wang X, Qian XD, Lin XJ, Chen XH and Gao RL: Effects of Panax notoginseng saponins on proliferation and differentiation in NIH3T3 cells. Chin J Integr Med 18: 616-620, 2012.

16. Li XD, Chang B, Chen B, Liu ZY, Liu DX, Wang JS, Hou GQ, Huang DY and Du SX: Panax notoginseng saponins potentiate osteogenesis of bone marrow stromal cells by modulating gap junction intercellular communication activities. Cell Physiol Biochem 26: 1081-1092, 2010.

17. Li XD, Wang JS, Chang B, Chen B, Guo C, Hou GQ, Huang DY and Du SX: Panax notoginseng saponins promotes proliferation and osteogenic differentiation of rat bone marrow stromal cells. J Ethnopharmacol 134: 268-274, 2011.

18. Jia C, Xiong M, Wang P, Cui J, Du X, Yang Q, Wang W, Chen Y and Zhang T: Notoginsenoside R1 attenuates atherosclerotic lesions in ApoE deficient mouse model. PLoS One 9: e99849, 2014.

19. Yu HS, Zhang LJ, Song XB, Liu YX, Zhang J, Cao M, Kang LP, Kang TG and Ma BP: Chemical constituents from processed rhizomes of Panax notoginseng. Zhongguo Zhong Yao Za Zhi 38: 3910-3917, 2013 (In Chinese).

20. Horii A, Wang X, Gelain F and Zhang S: Biological designer self-assembling peptide nanofiber scaffolds significantly enhance osteoblast proliferation, differentiation and 3-D migration. PLoS One 2: e190, 2007.

21. Fatokun AA, Stone TW and Smith RA: Hydrogen peroxideinduced oxidative stress in MC3T3-E1 cells: The effects of glutamate and protection by purines. Bone 39: 542-551, 2006.

22. Iwata T, Morotome Y, Tanabe T, Fukae M, Ishikawa I and Oida S: Noggin blocks osteoinductive activity of porcine enamel extracts. J Dent Res 81: 387-391, 2002.

23. Kuske B, Savkovic V and zur Nieden NI: Improved media compositions for the differentiation of embryonic stem cells into osteoblasts and chondrocytes. Methods Mol Biol 690: 195-215, 2011.

24. Galindo M, Pratap J, Young DW, Hovhannisyan H, Im HJ, Choi JY, Lian JB, Stein JL, Stein GS and van Wijnen AJ: The bone-specific expression of Runx 2 oscillates during the cell cycle to support a G1-related antiproliferative function in osteoblasts. J Biol Chem 280: 20274-20285, 2005.

25. Pratap J, Galindo M, Zaidi SK, Vradii D, Bhat BM, Robinson JA, Choi JY,Komori T, Stein JL, Lian JB, et al: Cell growth regulatory role of Runx 2 during proliferative expansion of preosteoblasts. Cancer Res 63: 5357-5362, 2003.

26. Kang X, Li Z, Zhang WH, Zhou Q, Liu RH and Wang XJ: Study on effect of combination of Epimedii Folium and Ligustri Lucidi Fructus on osteoporosis rats induced by retinoic acid. Zhongguo Zhong Yao Za Zhi 38: 4124-4128, 2013 (In Chinese).

27. Wang X, Zhen L, Zhang G, Wong MS, Qin L and Yao X: Osteogenic effects of flavonoid aglycones from an osteoprotective fraction of Drynaria fortunei - an in vitro efficacy study. Phytomedicine 18: 868-872, 2011.

28. Ma HP, Ming LG, Ge BF, Zhai YK, Song P, Xian CJ and Chen KM: Icariin is more potent than genistein in promoting osteoblast differentiation and mineralization in vitro. J Cell Biochem 112: 916-923, 2011.

29. Tsuji-Naito K: Aldehydic components of cinnamon bark extract suppresses RANKL-induced osteoclastogenesis through NFATc1 downregulation. Bioorg Med Chem 16: 9176-9183, 2008.

30. Gong W and Li F: Quality evaluation on different specifications of Cervi Cornu Pantotrichum with its effect on ovariectomized osteoporosis model rats. Zhongguo Zhong Yao Za Zhi 39: 2326-2329, 2014 (In Chinese). 
31. Zhong L, Zhou XL, Liu YS, Wang YM, Ma F, Guo BL, Yan ZQ and Zhang QY: Estrogen receptor $\alpha$ mediates the effects of notoginsenoside R1 on endotoxin-induced inflammatory and apoptotic responses in H9c2 cardiomyocytes. Mol Med Rep 12: 119-126, 2015.

32. Shi X, Yu W, Yang T, Liu W, Zhao Y, Sun Y, Chai L, Gao Y, Bin Dong and Zhu L: Panax notoginseng saponins provide neuroprotection by regulating $\mathrm{NgR} 1 / \mathrm{RhoA} / \mathrm{Rock} 2$ pathway expression, in vitro and in vivo. J Ethnopharmacol: June 8, 2016 (Epub ahead of print).

33. Wang P, Cui J, Du X, Yang Q, Jia C, Xiong M, Yu X, Li L, Wang W, Chen $\mathrm{Y}$ and Zhang T: Panax notoginseng saponins (PNS) inhibits breast cancer metastasis. J Ethnopharmacol 154: 663-671, 2014.

34. Yang BR, Cheung KK, Zhou X, Xie RF, Cheng PP, Wu S, Zhou ZY, Tang JY, Hoi PM, Wang YH and Lee SM: Amelioration of acute myocardial infarction by saponins from flower buds of Panax notoginseng via pro-angiogenesis and anti-apoptosis. J Ethnopharmacol 181: 50-58, 2016.

35. Wang T, Guo R, Zhou G, Zhou X, Kou Z, Sui F, Li C, Tang L and Wang Z: Traditional uses, botany, phytochemistry, pharmacology and toxicology of Panax notoginseng (Burk.) F.H. Chen A review. J Ethnopharmacol: May 3, 2016 (Epub ahead of print).

36. Wang X, Jiang L, Wang X, Yin F, Li G, Feng X, Wang K and Sun S Combination of autologous transplantation of G-CSF-mobilized peripheral blood mononuclear cells and Panax notoginseng saponins in the treatment of unreconstructable critical limb ischemia. Ann Vasc Surg 28: 1501-1512, 2014.

37. Lee BA, Lee HS, Jung YS, Kim SW, Lee YW, Chang SH Chung HJ, Kim OS and Kim YJ: The effects of a novel botanical agent on lipopolysaccharide-induced alveolar bone loss in rats. J Periodontol 84: 1221-1229, 2013.

38. Chen B, Li XD, Liu DX, Wang H, Xie P, Liu ZY, Hou GQ, Chang B and Du SX: Canonical Wnt signaling is required for Panax notoginseng saponin-mediated attenuation of the RANKL/OPG ratio in bone marrow stromal cells during osteogenic differentiation. Phytomedicine 19: 1029-1034, 2012.
39. Chen W, Dang Y and Zhu C: Simultaneous determination of three major bioactive saponins of Panax notoginseng using liquid chromatography-tandem mass spectrometry and a pharmacokinetic study. Chin Med 5: 12, 2010.

40. Sun Q, Meng QT, Jiang Y, Liu HM, Lei SQ, Su WT, Duan WN, Wu Y, Xia ZY and Xia ZY: Protective effect of ginsenoside $\mathrm{Rb} 1$ against intestinal ischemia-reperfusion induced acute renal injury in mice. PLoS One 8: e80859, 2013.

41. Song ZJ, Tang LL and Li GL: The protective function and mechanism of notoginsenoside Rbl against hypoxia hypercapniainduced pulmonary vasoconstriction. Zhongguo Zhong Xi Yi Jie He Za Zhi 32: 1380-1384, 2012 (In Chinese).

42. Shen Y, Li YQ, Li SP, Ma L, Ding LJ and Ji H: Alleviation of ovariectomy-induced osteoporosis in rats by Panax notoginseng saponins. J Nat Med 64: 336-345, 2010.

43. Logan DC: Bacteriological standards in the investigation of enteric convalescents. BMJ 1: 222-223, 1942.

44. Sasano Y, Li HC, Zhu JX, Imanaka-Yoshida K, Mizoguchi I and Kagayama M: Immunohistochemical localization of type I collagen, fibronectin and tenascin $\mathrm{C}$ during embryonic osteogenesis in the dentary of mandibles and tibias in rats. Histochem J 32: 591-598, 2000.

45. Son JH, Cho YC, Sung IY, Kim IR, Park BS and Kim YD: Melatonin promotes osteoblast differentiation and mineralization of MC3T3-E1 cells under hypoxic conditions through activation of PKD/p38 pathways. J Pineal Res 57: 385-392, 2014.

46. Okamura H, Yoshida K, Yang D and Haneji T: Protein phosphatase $2 \mathrm{~A} \mathrm{C} \alpha$ regulates osteoblast differentiation and the expressions of bone sialoprotein and osteocalcin via osterix transcription factor. J Cell Physiol 228: 1031-1037, 2013. 